\title{
Late Gothic Asymmetrical Diamond Vaults in Spain
}

\author{
Ana López-Mozo' ${ }^{1}$ (D) Rosa Senent-Domínguez ${ }^{1}$
}

\begin{abstract}
There are seven known cases in Spain of a particular type of late Gothic vault that also exists in at least 28 Central European buildings. They are tierceron vaults with diamond-shaped liernes and partially missing diagonal ribs. The design of this type of vault is not simple; thus, its dissemination seems to require a conscious copy of the model. Because the methods of designing the rib network were different in Spain and Central Europe and were only exchanged among masons, a volumetric and constructive analysis of these vaults that identifies their design techniques could support or question the existence of a technical knowledge transfer. After reviewing the existing examples in built heritage and written sources, this work analyzes the seven Spanish cases and studies the geometrical construction of their particular form, supported by accurate data on the vaults collected via topographic techniques.
\end{abstract}

\section{Hypothesis, Objectives and Methodology}

Gothic vaulting construction evolved in different ways in each European region and their connections have been supported by research mainly regarding the study of masters' travel routes and the similarities in typologies and ornamentation. However, we believe that this data cannot prove the existence of technical transfer. The presence of a master builder in a particular place and time is insufficient to confirm authorship or to support a master's participation in building a vault. In

Ana López-Mozo

ana.lopez.mozo@upm.es

Rosa Senent-Domínguez

rosa.senent@upm.es

1 School of Architecture, Polytechnic University of Madrid, Av. Juan de Herrera 4, 28040 Madrid, Spain 
addition, the same appearance in two different cases may be the result of a mere image copy transferred by any means or even a random outcome. For this reason, we attempt to find deeper connections than the mere repetition of a pattern.

The differences in the evolution of Gothic vaulting construction in each European region also involve the three-dimensional rib network design procedures. According to the analysis of Paul Frankl of the proceedings of the lodges meeting at Regensburg in 1459, these methods were only exchanged among masons: "Also no workman, nor master, nor parlier, nor journeyman shall teach anyone, whatever he may be called, not being one of our handicraft and never having done mason work, how to take the elevation from the ground plan" (Frankl 1945: 46). In addition, determining the threedimensional layout of a particular vault merely from an analysis of its visual appearance or even its plan layout is neither currently possible nor would have been possible for a medieval master builder; an explanation or the original tracings are needed. Thus, to distinguish a deeper relationship from mere copies of a pattern, it may be necessary to consider a geometrical and constructive three-dimensional analysis. We are currently studying technical knowledge transfer in the context of European late Gothic from an analysis of the actual geometry of vaults that appear to be similar.

Our paper is focused on the study of a particular type of vault that appears in at least 35 buildings across Europe and four original written sources. They are tierceron vaults with diamond-shaped liernes and partially missing diagonal ribs. This pattern, with a central rhombus aligned with the diagonals of the plan, features no symmetry about the main axes of the plan. However, when spanning a square bay, the vault is symmetrical about the diagonals. It is not a simple design and does not seem to arise from a mere process of rib multiplication. At a minimum, a conscious copy of the pattern is needed. This article examines the Spanish examples of this type of vault and describes an approach to the rib network design process. The objective is to establish relationships between the Spanish examples and the rest of the known cases and either support or dismiss the existence of a technical knowledge transfer based on evidence beyond the apparent similarities or the documented presence of a master mason at a particular place and time.

This present study is supported by data collection based on photogrammetric and topographic techniques. We have measured the vaults using a total station in three cases (Zamora, Segovia and Auñón), crossing image photogrammetry in one case (Villegas) and automated photogrammetry in three other cases (Corrales del Vino, Atapuerca and Mahamud). However, to obtain orthophotos of the plan, all of the stations have been processed by automated photogrammetry. In working with the three-dimensional configuration of the rib network, with all the techniques, we obtained points of the intrados of the ribs. Because they are not large vaults and there are no relevant slants, we have not computed the deformations.

\section{Drawings Related to This Layout in Written Sources}

Written sources contain at least eleven drawings representing these types of vaults. They depict the plan layout but do not contain information regarding the three-dimensional design of the rib network. Three of these sources can be found in the Musterbuch of Hans 
Hammer, master of Strasbourg Cathedral at the end of the fifteenth century (Hammer ca. 1500), five sources are in the Wiener Sammlungen Collection and are dated from the fifteenth and sixteenth centuries (Böker 2005), two sources are in the Frankfurt Lodge Book of Master WG, dated ca. 1560 (Bucher 1979) and one source is in the Bauhüttenbuch des Wolfgang Rixner (Rixner 1445-1599) (Fig. 1).

These eleven drawings of the model have been identified in Central European written sources, but not one has been found in the Spanish texts. Most of these drawings seem to be theoretical layouts that do not depict actual vaults, and they span square bays. No drawing shows an entire diagonal rib (one of them is frequently missing), which leaves the central rhombus empty. The design process may have begun in all cases by determining the position of the tiercerons. Ten of the drawings perform this step by dividing the diagonal, the side, the axis or the diameter of the circumscribed circle into equal parts. Only one drawing shows a different method: it appears to have been begun by aligning the tiercerons with the intersection of the axes and the circumscribed circumference (Fig. 1, 1b).

Interestingly, three of these sources belong to three different collections but may have followed a similar design process (Fig. 1, 1a, 2a, 3a). All of them span a square bay and present a design with partially or completely missing diagonal ribs. Considering the possibility of the introduction of errors during the process of reproducing and scanning the drawings and the possible original inaccuracy of the drawings, the design process may have begun by placing the tierceron keystones on a $4 \times 4$ grid, that is, laying out the tiercerons so that they are aligned with the midpoint of each corresponding side. Then, the keystones on the largest rhombus diagonal may have been aligned with the tiercerons. The central rhombus is laid out connecting these keystones with those of the tiercerons. This method of locating the keystones on the largest rhombus diagonal also divides the enclosing square diagonal into three equal parts.

\section{Existing Vaults of This Type in Europe}

A total of 47 vaults of this type have been thus far identified in 35 buildings constructed throughout Europe during the fifteenth and sixteenth centuries. ${ }^{1}$ Because there is such a large number of late Gothic constructions, more cases may remain unknown. The work by Stefan Bürger (2007) on late Gothic vaults in Saxony identified more than 600 cases in this region alone. Currently, we have found nine buildings with vaults of this type in Poland, two in Switzerland, five in Germany, three in Austria, one in Hungary, two in the Czech Republic, four in France, two in the Netherlands (one of them rebuilt) and seven in Spain (Fig. 2). The earliest examples hitherto known were all located in Silesia, currently southwestern Poland.

\footnotetext{
1 There are 12 cases that feature two vaults of this type in the same building, which is why we list 47 vaults in 35 buildings. Nine of these 12 cases present the two vaults side by side. In addition, there were at least three more buildings with vaults that follow this design, but they no longer exist. A vault of this type located in the cloister of the Schottenkirche in Vienna was demolished in 1831 (Reidinger 2007: 194). The vault in St. Peter's church in Frankfurt was demolished in 1895 (Nussbaum 1999 n. 861). Four vaults that follow this pattern were built ca. 1474 in the Fuggerhaus in Augsburg, which was destroyed in 1945. We wish to thank Thomas Bauer for providing the data on the vaults in Augsburg.
} 
e

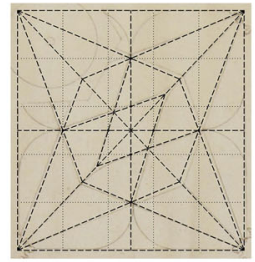

d
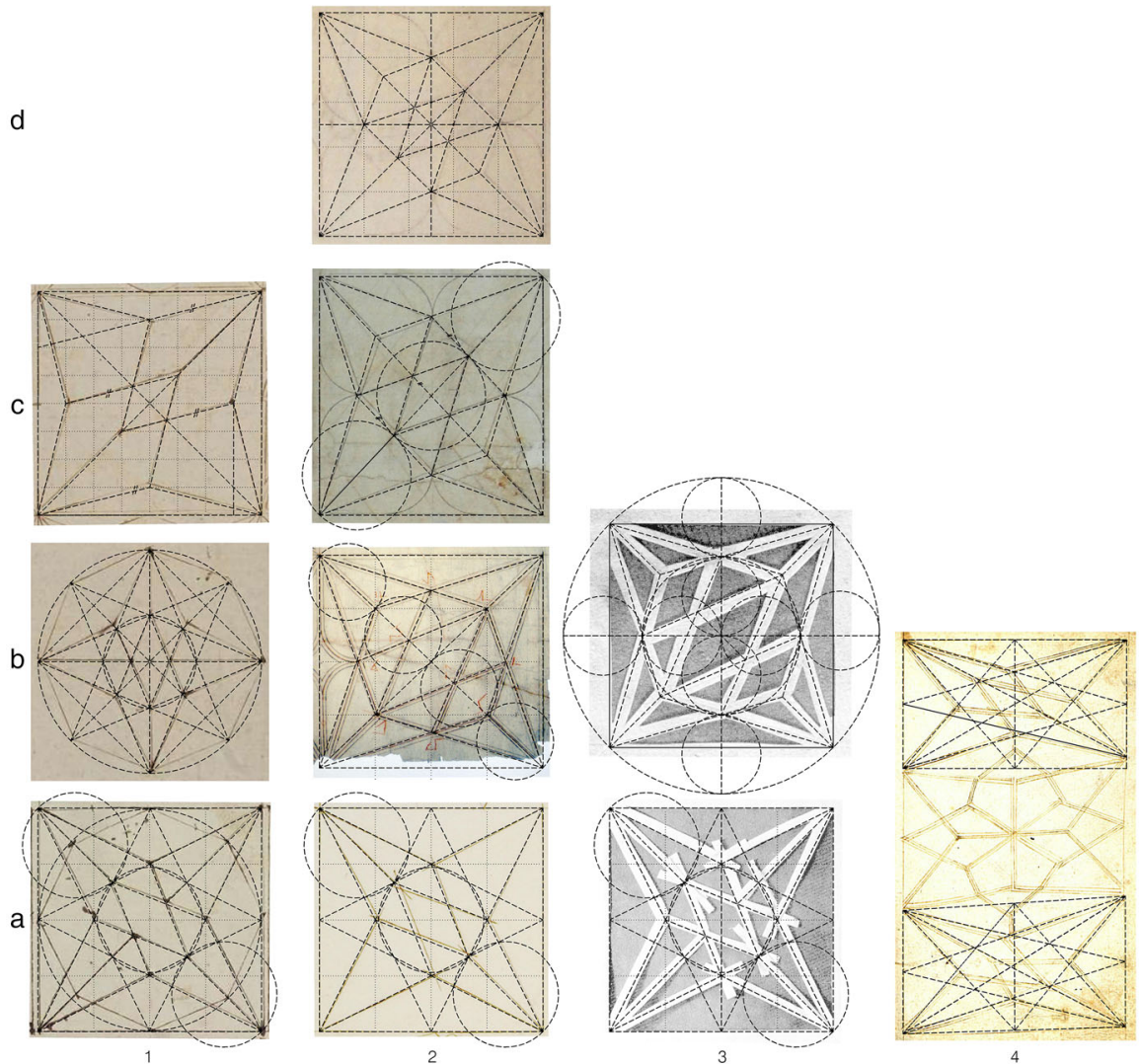

Fig. 1 Geometric layouts in drawings related to asymmetrical diamond patterns in original written sources. $1 a-c$ Musterbuch of Hans Hammer (15th-16th century: fols 26v, 28v, 29). ${ }^{\circ}$ Herzog August Library Wolfenbüttel; 2a-e) Wiener Sammlungen Collection (15th-16th century: fols. 16818, 16903, 16941, 17015v and 17019). Images reproduced by permission of the Kupferstichkabinett der Akademie der bildenden Künste Wien (see also Böker 2005); 3a-b) Frankfurt Lodge Book of Master WG (15601572: fols. 133 and 140). Images ${ }^{\circ}$ Städel Museum, Frankfurt am Main, reproduced by permission (see also Bucher 1979); 4a) The lodge book of Wolfgang Rixner, Jerg Reiter and others (1445-1599: fol. 262). Images: Albertina, Vienna, reproduced by permission. Black overlays on all images by the authors

The earliest vaults, just $50 \mathrm{~km}$ away from one another, are located at Nysa, in a chapel at the parish church of St. James, built ca. 1390, which spans an irregular quadrilateral bay, and at Głogówek, in the collegiate church of St. Bartholomew, where there are two rectangular vaults built ca. 1417-1419 (Adamski 2013: 103) (Fig. 3). 


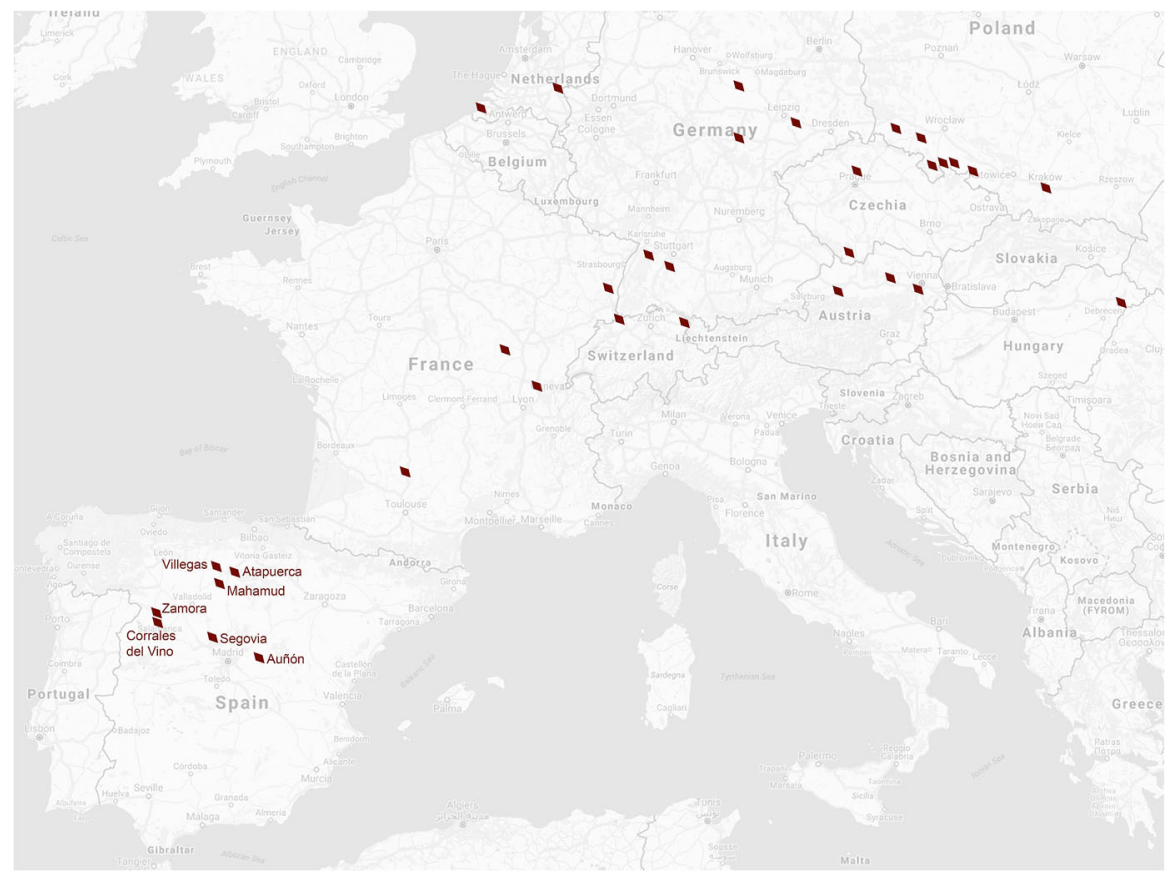

Fig. 2 European asymmetrical diamond vaults in our current collection. Image: authors

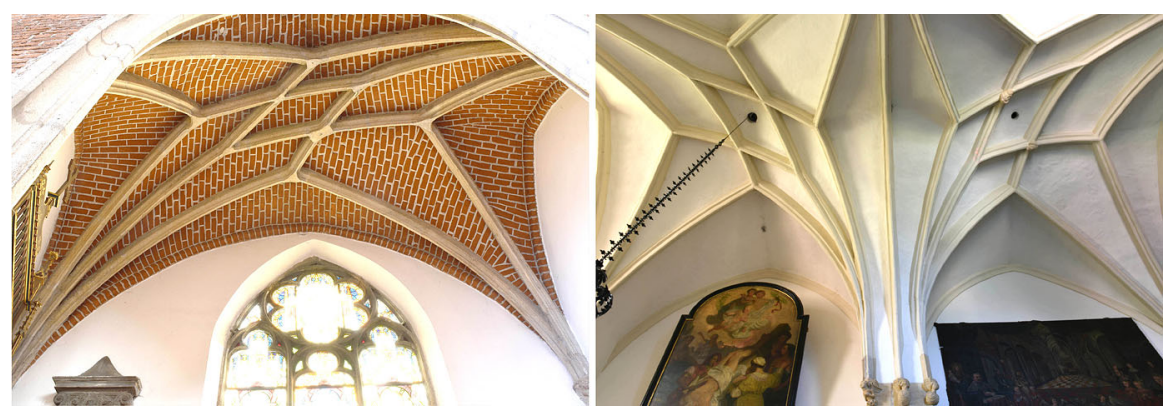

Fig. 3 Earliest vaults following an asymmetrical diamond design: Nysa, parish church of St. James (left) and Głogówek, in the collegiate church of St. Bartholomew (right). Photographs: authors, 2016

We have documented 46 actual vaults through our own visit or by consulting existing drawings and pictures. These vaults are located in chapels (13), aisles (11), cloisters (9; 5 of them at a cloister corner), naves (4), crossings (2), transepts (2), vestries (2), choirs (1), basements (1) and towers (1). It has been possible to determine the plan proportions of 41 vaults. Only seven of them span a square plan; the rest are rectangular and, in some cases, irregular. Thus, this asymmetrical design appears to have been a useful resource for spanning rectangular bays. An analysis of the rib pattern type shows that the most frequent design features a single central diamond, one diagonal rib missing and an incomplete remaining rib, which leaves 
46 cases

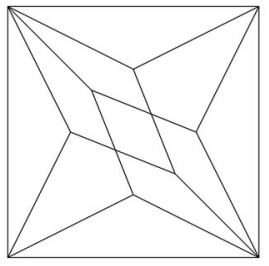

$25 / 46$

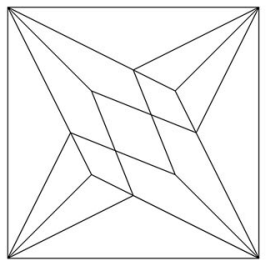

$6 / 46$

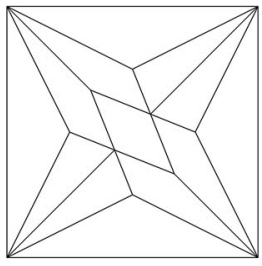

$8 / 46$

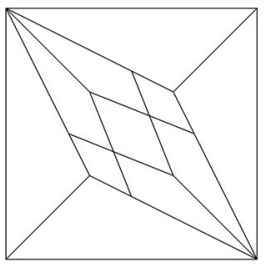

$1 / 46$

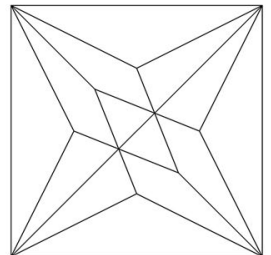

$4 / 46$

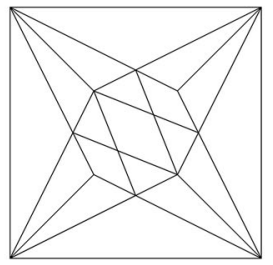

$1 / 46$

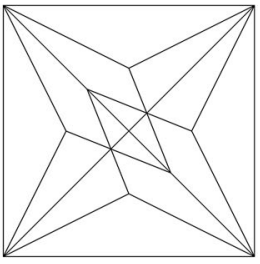

$1 / 46$

Fig. 4 Most common patterns in our current collection of asymmetrical diamond vaults, drawn on a square plan. Images: authors

the central rhombus empty. This design is present in 25 of the 46 registered vaults. Eight vaults in our current collection feature no missing diagonal ribs and a central empty diamond. Four vaults feature one complete diagonal rib, one shows both diagonal ribs complete, and eight show a triple central diamond (one of them completes an exterior octagon) (Fig. 4).

The most frequent pattern in our collection, a vault with a missing diagonal rib, may be particularly useful in rectangular plans. A common Gothic designing practice was to trace a regular central figure, perhaps to hide the irregularities of boundary conditions (Huerta 2005: 10). Possibly applying this idea to the asymmetrical diamond design that we examine here, some patterns feature secondary keystones equidistant to the center. In this case, the keystones on the shorter rhombus diagonal are unaligned with the corners, and materializing the entire diagonal with an actual rib would result in four unaligned pieces of rib. To avoid this problem, the corresponding diagonal rib would be removed (Fig. 5).

\section{Late Gothic Three-Dimensional Rib Network Design Methods}

Existing research concerning rib network three-dimensional design in fifteenth and sixteenth century written sources allows us to observe some important differences between Spanish and French methods and Central European methods (Palacios 2009; Rabasa et al. 2015). Spanish layouts that contain information on threedimensional rib network design can be found in the works by Hernán Ruiz (ca. 1558), Rodrigo Gil de Hontañón (ca. 1560) included in Simón García (1681), 


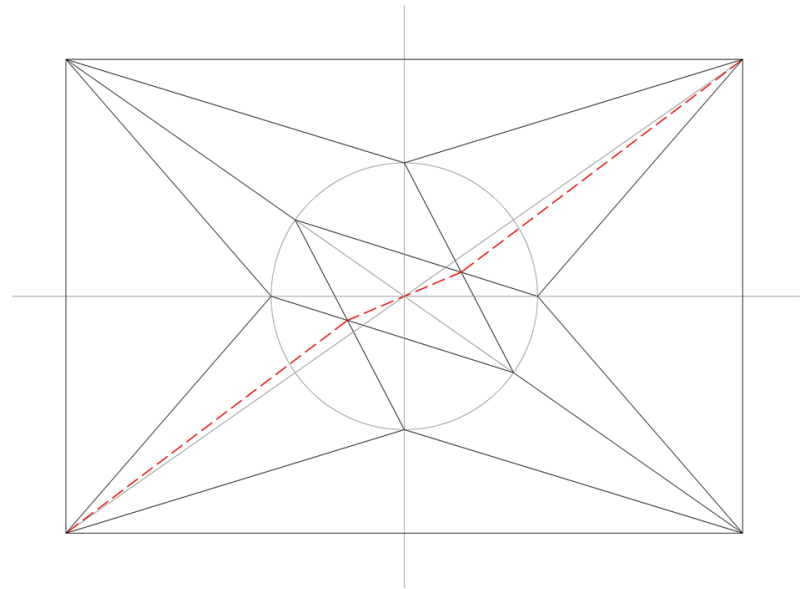

Fig. 5 Misalignment of the various portions of the diagonal rib when the secondary keystones are equidistant to the center in a rectangular-plan vault. Images: authors

Vandelvira (ca. 1575) and Alonso de Guardia (ca. 1600). The only French text of this period regarding the three-dimensional design of Gothic vaults is by Delorme (1567: 107-109). ${ }^{2}$ A somewhat complex tierceron vault, similar to the pattern that this paper focuses on, is depicted in all of these Spanish and French layouts. Regarding the plan design, Vandelvira traces the tiercerons aligned with the midpoint of the corresponding side; the rest of the authors, however, align them with the intersection of the axes and the circumscribed circumference, giving as a result that each tierceron follows the bisector of the wall arch and the diagonal rib (Calvo 2016). Concerning the three-dimensional design, all of the authors lay out a semicircular diagonal rib. Then, Hernán Ruiz traces the radius of the lierne twice the size of the diagonal rib (Rabasa 1996: 428). Delorme also lays out the liernes with a larger radius than the one of the diagonal rib. ${ }^{3}$ On the contrary, Rodrigo Gil, Vandelvira and Alonso de Guardia trace the ribs as arcs of the same sphere, so both diagonal ribs and liernes match the same curvature (Palacios 2006; Calvo 2017). Thus, all the mentioned Spanish and French sources present layouts with different rib curvatures in each design. They seem to be theoretical layouts with a didactic purpose of establishing basic principles; actual built vaults feature a much richer variety of solutions (Rabasa et al. 2015: 1399-400) (Fig. 6).

Fifteenth and sixteenth century written sources in Central Europe are mainly sketchbooks or collections of drawings with a rich variety of solutions. We have studied their contents searching for information on original procedures for threedimensional vault design. The Musterbuch of Hans Hammer contains vault

\footnotetext{
${ }^{2}$ Delorme includes two rib vault layouts in his treatise; one involves a tierceron vault, and the other reflects the nave and apse of a church; this present study analyzes the tierceron vault.

3 A graphical interpretation of Delorme's layout is shown in Fig. 6. If the ribs had been designed as arcs of the same sphere, the point 4 should have been located at the same height of the springings of the vault. An analysis of Delorme's layout was also carried out by Huerta (2016: 300-303), approaching all the steps of the design process.
} 


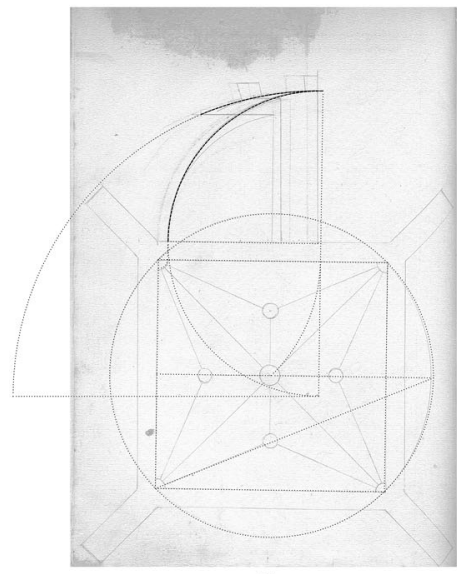

a

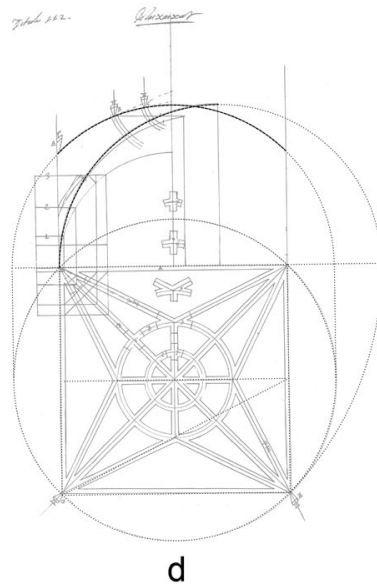

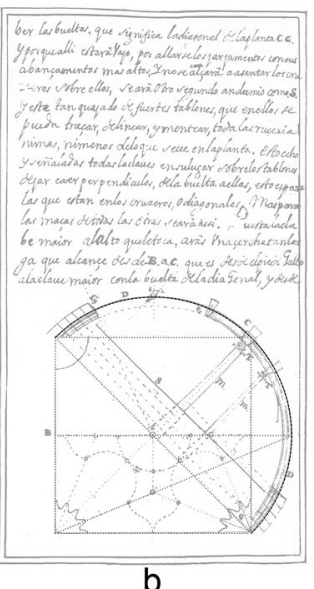

b

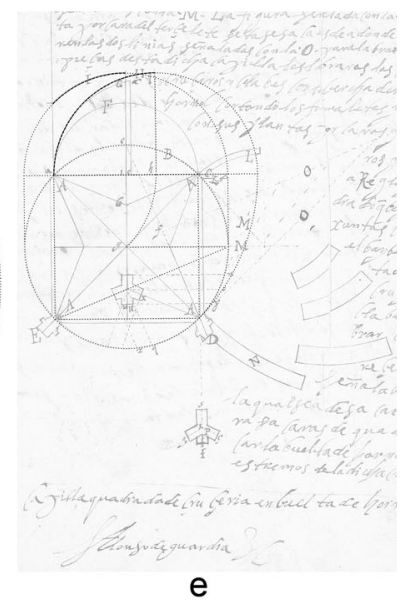

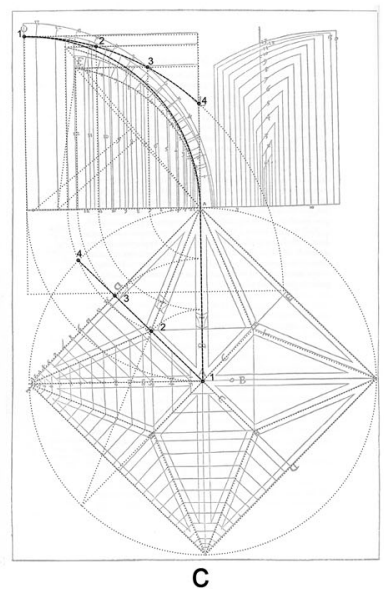

C

Fig. 6 Three dimensional rib-vault design methods in Spanish and French written sources from the sixteenth century. a works by Hernán Ruiz (ca. 1558, fol 46v, image reproduced by permission of the Bibloteca de la Escuela Técnica Superior de Arquitectura-Universidad Politécnica de Madrid); b Rodrigo Gil de Hontañón (ca. 1560: fol 25, image reproduced by permission of the Biblioteca Nacional de España, Madrid); c Delorme (1567, 108v); d Vandelvira (ca. 1575: 112, image reproduced by permission of the Biblioteca de la Escuela Técnica Superior de Arquitectura-Universidad Politécnica de Madrid); e Alonso de Guardia (ca. 1600, image reproduced by permission of the Biblioteca Nacional de España, Madrid). Black overlays by the authors

elevation layouts in fols. 23v, 24, 24v and 33v (Hans Hammer ca. 1500). The Wiener Sammlungen Collection (fifteenth and sixteenth century) presents layouts regarding rib elevation design in fols. 16910v, 16919 and 16930 (Böker 2005). The Bauhüttenbuch des Wolfgang Rixner contains a drawing related to three-dimensional vault design (Rixner 1445-1599: 8). The Frankfurt Lodge Book of Master WG (ca. 1560; Bucher 1979) shows the layouts of independent arches on fols. 37-38, 40-45 and 47-48 and coordinated ground plan/elevation layouts on fols. 13, 21, 32, 39 and 46. All 23 pages of Codex Miniatus 3 (ca. 1560-70; Müller 2005) 
reflect three-dimensional vault designs. The treatise by Jakobus Facht von Andernach includes three-dimensional information in 18 layouts (1593: fols. 3v$16,17 \mathrm{v}-19,22 \mathrm{v}$ and $28 \mathrm{v})$.

The most frequent procedures to derive elevation from the ground plan that are depicted in the mentioned Central European written sources show that laying out the vault requires a drawing of the ground plan and an elevation of a usually semi-circular arch, called a Prinzipalbogen (main arch). ${ }^{4}$ This main arch forms all the ribs and allows the determination of the height of any keystone. The radius of this main arch is established by the unfolding of one of the ways determined in the ground plan to go from the springing to the point with the highest position in the rib network. The height of each keystone depends on the length that may be travelled along the rib network to reach its position, which must be unfolded on the base of the main arch (Müller et al. 2005). ${ }^{5}$ Thus, the geometric operations are extremely simple, even in a complex vault (Müller and Quien 2005; Pliego 2011; Rabasa et al. 2015). The system provides many different volume solutions for a particular ground plan (Fig. 7).

Research on three-dimensional rib network design requires not only analyzing written sources but also determining the actual geometry of built vaults. Different types of three-dimensional design that might be related to the use of a main arch to guide the process have been identified in actual vaults. The asymmetrical diamond vault located at the crossing of Bebenhausen Abbey's church, built in 1467 (Böker 2005 , 217), follows a design with a unique rib curvature radius obtained from half the diagonal of the plan. However, the keystone heights are previously determined, six of them at the same level, and some of the tiercerons are put forward and elevated to reach them avoiding their different lengths because of the rectangular form of the plan; thus, the unfolding system was not applied here (López Mozo et al. 2015a). The vault at the Antigua Chapel in Seville Cathedral, designed by Simon of Cologne ca. 1504 (Gómez Martínez 1998: 86), features different rib curvatures, and the heights of the keystones may have been obtained by projecting them onto the plane of the diagonal rib and then measuring the height of the corresponding point in the arch (Martín Talaverano et al. 2012).

\section{Spanish Asymmetrical Diamond Vaults}

Seven vaults that follow this layout have been identified in Spain (Fig. 8). A vault model of this type has also been found in one of the canopies located in the pillars of the royal chapel of the Catholic Monarchs Hospital at Santiago de Compostela; it was finished in 1511 following the project by Enrique Egas (Villaamil 1903: 475).

\footnotetext{
${ }^{4}$ Procedures based on the use of a main arch are present in the collections of Hans Hammer (ca. 1500) Rixner (1445-1599) Codex Miniatus 3 (ca. 1560-70), Wiener Sammlungen (fifteenth and sixteenth century) and Jakobus Facht von Andernach (1593).

5 A later author, Ranisch (1695), presents a different procedure. He takes half the diagonal of the plan to set the radius of the main arch. His method to compute the height of any keystone, as it has been traditionally understood, requires measuring its horizontal distance to the centre of the vault and placing it on the base of the main arch. However, Rabasa et al. pose that Ranisch unfolds the mentioned horizontal distance on the main arch itself from its apex (Rabasa et al. 2015: 1403).
} 


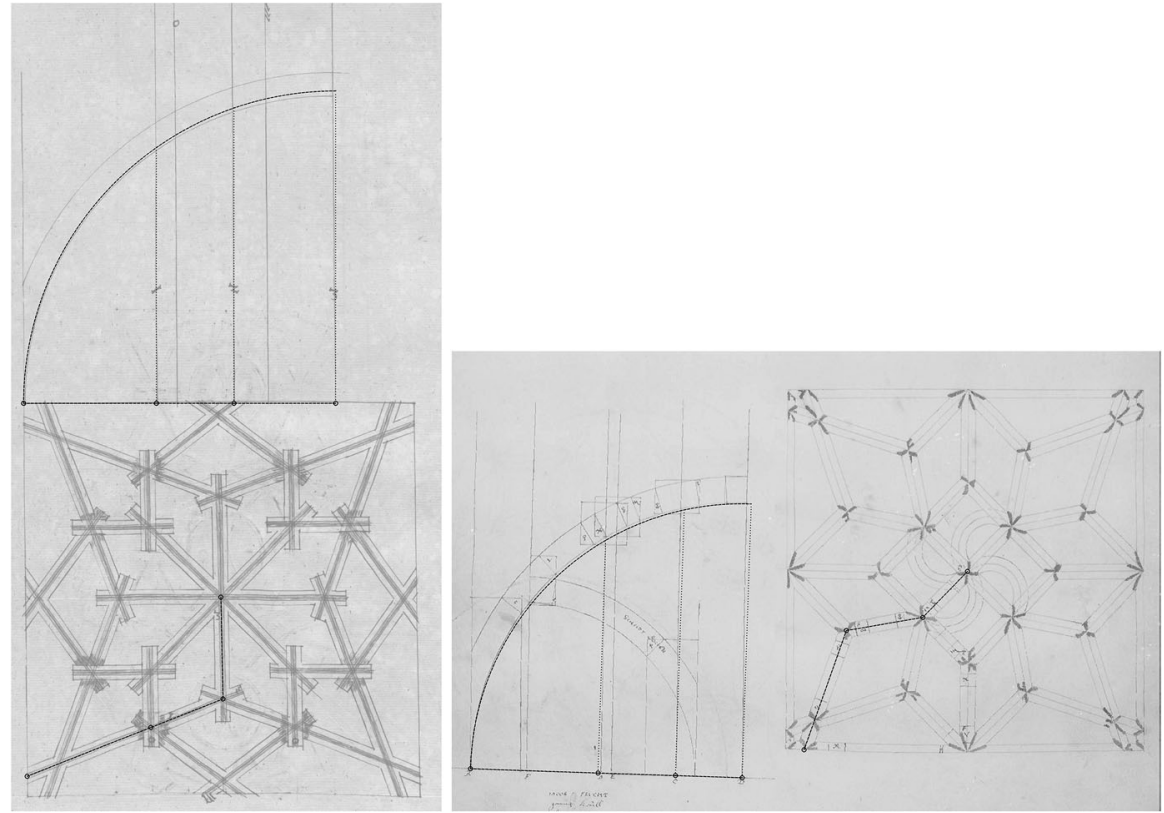

Fig. 7 Three dimensional design methods in Central European written sources. On the left, Codex Miniatus 3 fol. 3v (ca. 1560-70) Images: Österreichische Nationalbibliothek, Vienna, available at onb.ac.at, reproduced by permission (see also Müller et al. 2005: 104); on the right, Treatise by Jakobus Facht von Andernach (1593; fol 15v and 16r) Images: Historische Archiv Köln, reproduced by permission. Black overlays by the authors, according to Müller 2005: 13, 36

This micro-vault follows a design with both diagonal ribs partially missing. In addition, a sketch of this type of vault has been found in the walls of a tracing house at the castle of Benissanó (Zaragozá 2008: 32, 33). The traces may be dated at the beginning of the sixteenth century, according to the buildings depicted in the drawings (Iborra 2014). The sketch depicts a design with both diagonal ribs complete (Fig. 9).

In what follows we will briefly describe the seven vaults.

1. The earliest of the Spanish examples is located at the feet of Zamora Cathedral and was built before 1466 (Ramos de Castro 1982: 319). This example is a rectangular-plan chapel divided into two rectangular parts, one of which is spanned by the vault that we focus on here. This vault features a single, central diamond, one diagonal rib missing and an incomplete remaining one. As mentioned, it is the most frequent design in Central Europe.

2. A second example is the vault at the cloister of Segovia Cathedral, built between 1473 and 1491 by the master Juan Guas from Brittany, originally at the old cathedral cloister, which was disassembled and raised again at the new cathedral site between 1524 and 1529 by Juan Campero (Merino de Cáceres 1996: 479-480). The vault has a square plan with no missing and incomplete diagonal ribs. Although both of these ribs are interrupted as they meet the central diamond, a small projection draws the diagonals of the rhombus. 

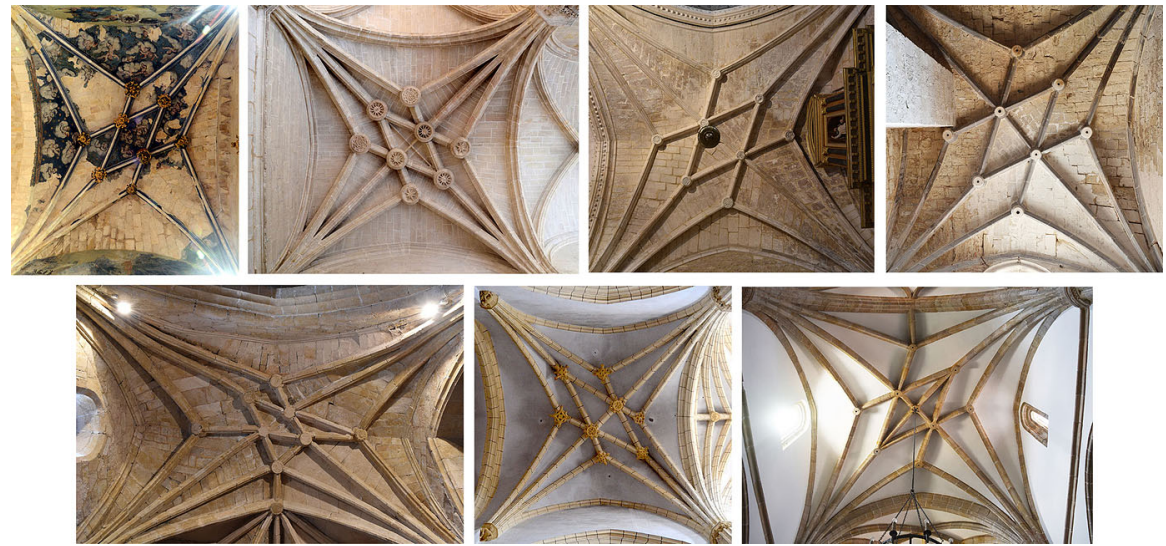

Fig. 8 Spanish asymmetrical diamond vaults. From left to right Zamora, Segovia, Atapuerca and Mahamud (top) and Corrales del Vino, Villegas and Auñón (bottom). Photos: authors, 2013-2016
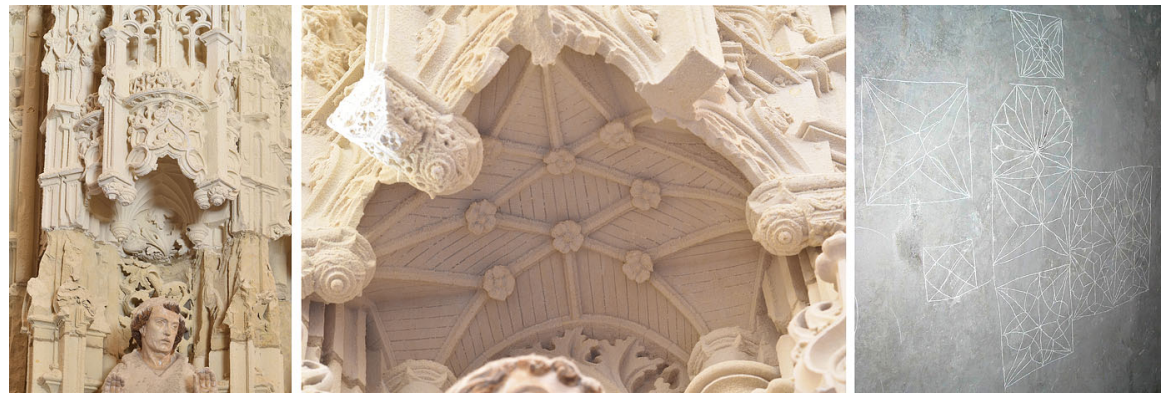

Fig. 9 On the left and centre, canopies located in the pillars of the royal chapel of the Catholic Monarchs Hospital at Santiago de Compostela (photograph by Enrique Rabasa 2016; photograph by the authors 2016); on the right, sketches in the walls of the tracing house at the castle of Benissanó. Photo: Arturo Zaragozá 2008, reproduced by permission

3. A third case is a vault at the Parish Church of Atapuerca in Burgos on the Route of Santiago de Compostela, thought to have been built at the end of the fifteenth century (Martín 2013: 901). The plan is slightly irregular, almost square. There is no missing diagonal rib, and one of them is complete. It features a different, much smaller cross section in the central part inside the diamond.

4. The Parish Church of Mahamud, also in the province of Burgos, and only $50 \mathrm{~km}$ away from Atapuerca, the preceding case, is a fourth example. This church was built in 1511 (Martín Martínez 2013: 1240). The apparent layout is similar to that of Atapuerca: there is no missing diagonal rib and one is complete. The buttress seems to have been placed after the wall was built, because it interrupts the door, and there are no connections in the arrangement of both fabrics.

5. The Parish Church of Corrales del Vino, very close to the first Spanish case at Zamora Cathedral, is a fifth case, and it was built in the first quarter of the 
sixteenth century (Vicente Pradas 2016: vol. 2, 117). As in Segovia, there are no missing diagonal ribs, and both are incomplete.

6. The sixth case is a vault at the Parish Church of Villegas (Burgos), a small village on the way to Santiago de Compostela, and it may have been built before 1571 (Ibáñez 1991: 342). The vault spans a square plan and, in this case, one of the diagonal ribs is complete.

7. The seventh example is a vault in the Parish Church in the small village of Auñón (Guadalajara), which was likely built between 1549 and 1583 (Muñoz 1987: 133). This vault is the only case in our sample that features two entire diagonal ribs.

The vault at Corrales del Vino shows no order and no organization; the ribs are unaligned, and the central keystones have lost their arms. Lacking documentary evidence, the vault appears to have collapsed, at least partially. Because this chaos in the arrangement of the vault makes its study non-viable, it has been discarded from analysis. Therefore, we analyzed six examples.

\section{Plan Layout}

The earliest Spanish case, the vault in Zamora Cathedral, shows a layout with a missing diagonal rib and an incomplete remaining rib. It is the most frequent design in Central Europe. Subsequent Spanish examples gradually begin to include complete diagonal ribs. The vault at Segovia has no diagonal ribs missing and both ribs are incomplete; Atapuerca, Mahamud and Villegas present no missing diagonal ribs, and one rib is complete; and Auñón shows two entire diagonal ribs (Fig. 10).

Designing the six cases may have begun by dividing the side or the diagonal into equal parts to place the tiercerons keystones. The next step of the process may be the same in the two first examples at Zamora and Segovia: the keystones on the diagonal rib that contains the largest rhombus diagonal are placed on the same circumference. These keystones may be determined at Villegas by dividing the free span of the arch into four equal parts and at Auñon by extension of the tiercerons. At Mahamud, the tiercerons are aligned with the midpoint of the side. At Atapuerca, the tiercerons are placed by drawing the liernes parallel to the tiercerons. Finally, the keystones on the remaining diagonal rib are determined by the diamond layout in all cases (Fig. 11).

Regarding the plan layout of the vault at Mahamud, it is remarkable that the various portions of diagonal ribs are not aligned, especially the ones with a missing central part. However, this irregularity is difficult to appreciate with the naked eye.

\section{Three-Dimensional Rib Network Design}

Concerning the design of the three-dimensional rib network, the six cases follow different methods but present some similarities. The four earliest examplesZamora (1466), Segovia (1499), Atapuerca (end of the fifteenth century) and Mahamud (1511) — may have been designed mainly by using a single rib curvature. 


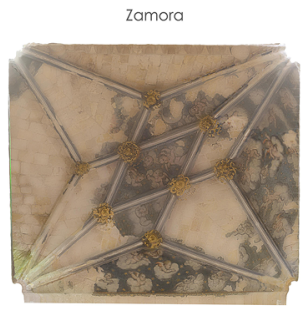

Segovia
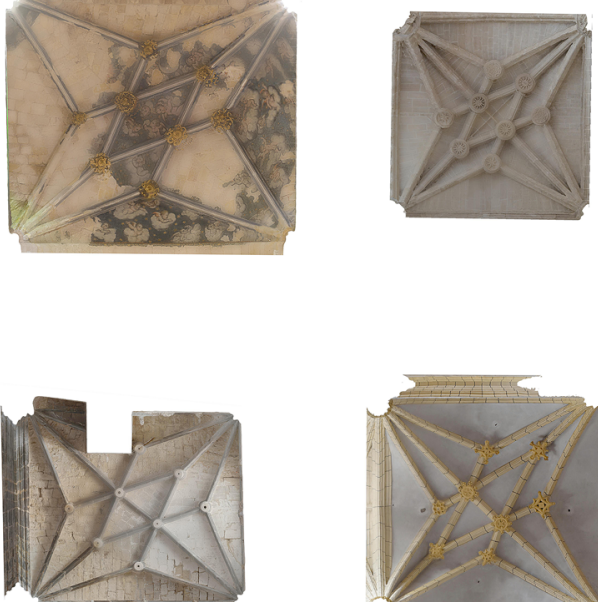

Mahamud

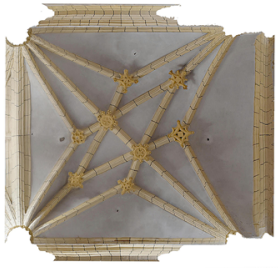

Villegas
Atapuerca
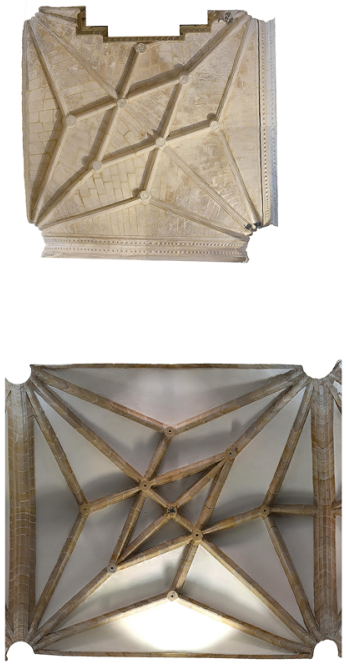

Auñón

Fig. 10 Orthophotos of the six Spanish vaults analyzed in this paper, obtained by automated photogrammetry. Image: authors
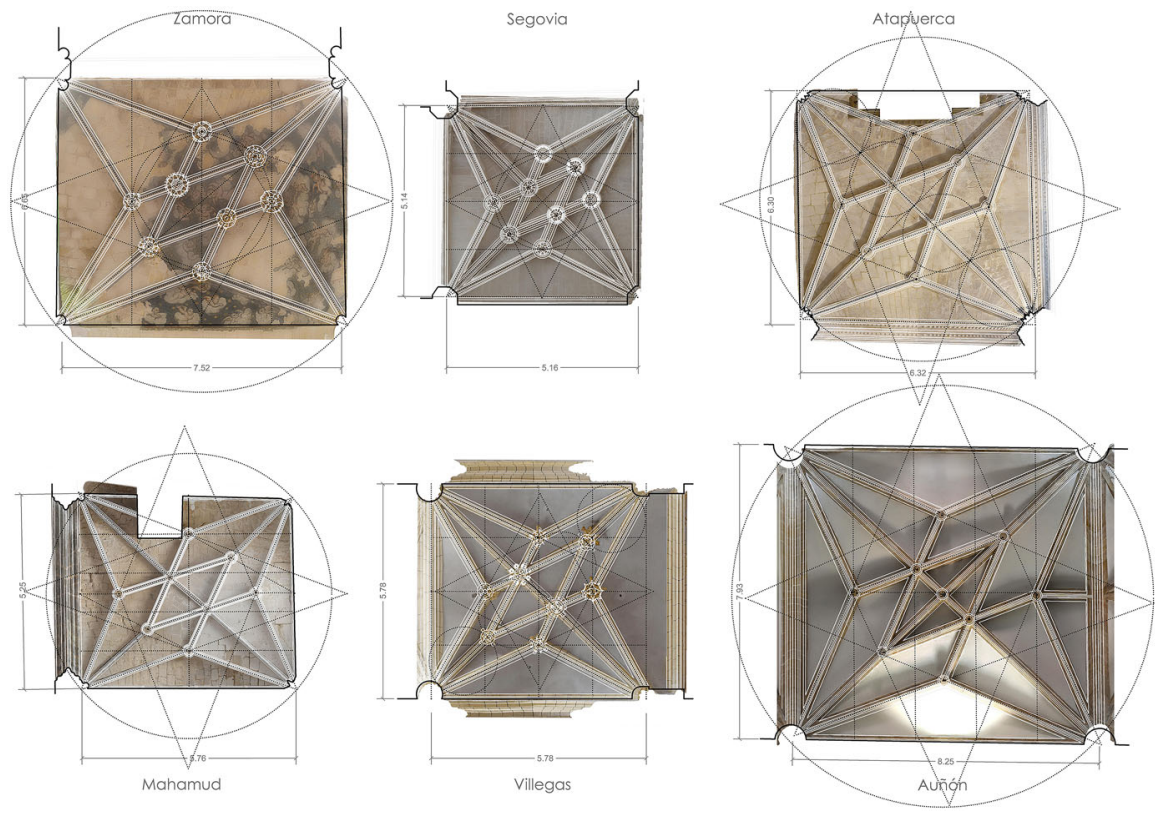

Fig. 11 Plan layouts of the Spanish vaults: Images: authors 
Note that the vaults at Atapuerca and Mahamud are both located in the province of Burgos, just $50 \mathrm{~km}$ away from one another.

Zamora's vault features a semi-circular diagonal rib. Its keystones and the keystones on the tiercerons, which are placed in the ground plan at the same distance from the center, are not at the same height; thus, the common Spanish design procedure that uses the curvature of the diagonal rib in transversal sections, present in the later original layouts by Gil de Hontañón, Vandelvira and Alonso de Guardia, must be discarded. The keystones on the tiercerons are placed at the same height from the mid-point of the diagonal rib, which is usually the top of a vault. Because of the rectangular shape of the plan, there are two types of tiercerons, one shorter than the other. All the ribs seem to have been traced using the same curvature, that of the diagonal rib. To reach the predetermined height of their keystones, the arcs forming the longer tiercerons are elevated $10 \mathrm{~cm}$ and the shorter $16 \mathrm{~cm}$. Although it is difficult to confirm due to their short length, the liernes also seem to have been designed with the same curvature; their centre is also elevated $16 \mathrm{~cm}$ from the springing level. In addition, with regard to the different length of the two pieces of liernes that spring from the tiercerons' keystones and meet at the missing diagonal rib keystones, they are designed with two independent pieces of arc featuring the same curvature (Fig. 12, left).

The diagonal ribs and tiercerons at Segovia's vault feature a different cross section, but have the same thickness, $35 \mathrm{~cm}(1.25$ Segovian feet of $28 \mathrm{~cm})$, and the same curvature radius, which is smaller than half of the span, though their centers are placed at different heights. At the springing, the tiercerons do not feature vertical tangents (Palacios 2009: 174-176). The six keystones that are equidistant from the center are placed at different heights; again, the layout reflected in three Spanish texts of the sixteenth century, which sets the ribs as sections of a sphere, was not applied here. If we take the distance from the keystone on the diagonal rib (the rib containing the smaller rhombus diagonal) to the keystone on the tierceron and place it on the diagonal rib, it matches the height of our tierceron's keystone. This matching may be because of the use of one of the versions of the above-mentioned main arch procedure in the Central European sources. The diagonal rib layout may be explained by the same method; if we unfold the way marked in dashed line in the ground plan, the total length is just double the diagonal rib radius (Fig. 12, right).

All the ribs at Atapuerca feature the same curvature and the same cross section (except for the central smaller rib). Thus, all the voussoirs are equal to one another, and the construction process is easier. The three-dimensional geometry of the vault at Mahamud is similar, but the liernes feature a different curvature. Due to the irregularity of the plan, the length of the diagonals is different. To lay out both diagonal ribs with the same arc, the one over the largest diagonal of the plan is formed by two separated arcs (Fig. 13).

All keystones in the Villegas vault are placed at the same height from the theoretical diagonal rib keystone. Both diagonal ribs are then formed by arcs of a circle, connected by a horizontal segment. The curvatures are different, and the diamond-shaped liernes are horizontal. Auñón's vault is built over an irregular rectangular plan, and it may have been designed using only three different rib radii. Because of the form of the plan, the diagonal ribs have different lengths and 

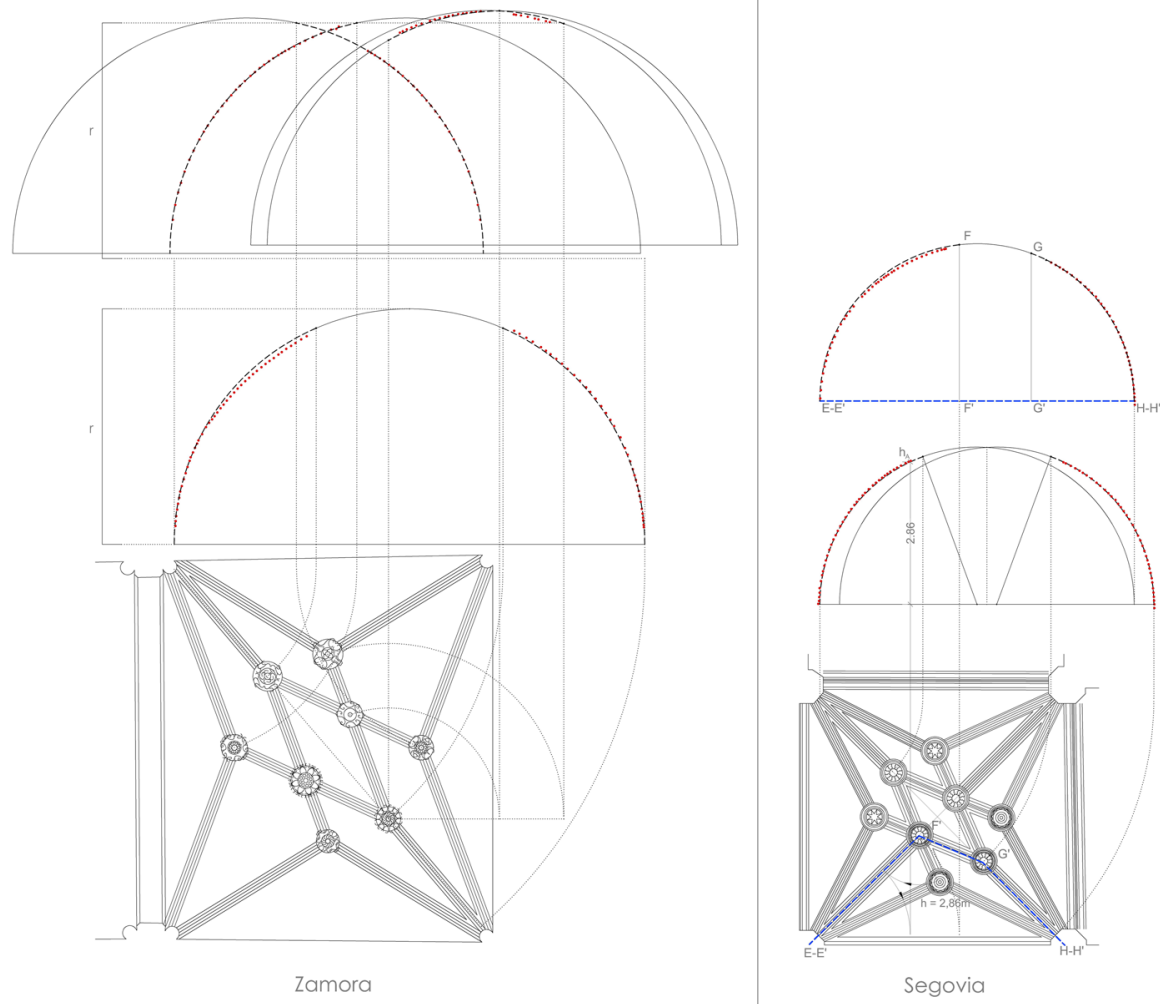

Fig. 12 Three-dimensional layout of the vaults at Zamora and Segovia. Images: authors

curvatures. Two of the tiercerons have the same curvature as one of the diagonal ribs, and the central diamond matches the radius of the other one. Thus, the remaining six tiercerons and all the perimeter arches feature the same curvature. The springings of the arches and the tierceron keystones are placed at different heights (Fig. 14).

\section{Conclusion}

The analysis of asymmetrical tierceron vaults with diamond-shaped liernes addressed in this paper, comprising the study of six existing Spanish vaults and written original sources from Spain and Central Europe, allows reaching some conclusions regarding the design process, which seems to be divided into two main steps: first laying out the plan and subsequently designing the three-dimensional rib network. 

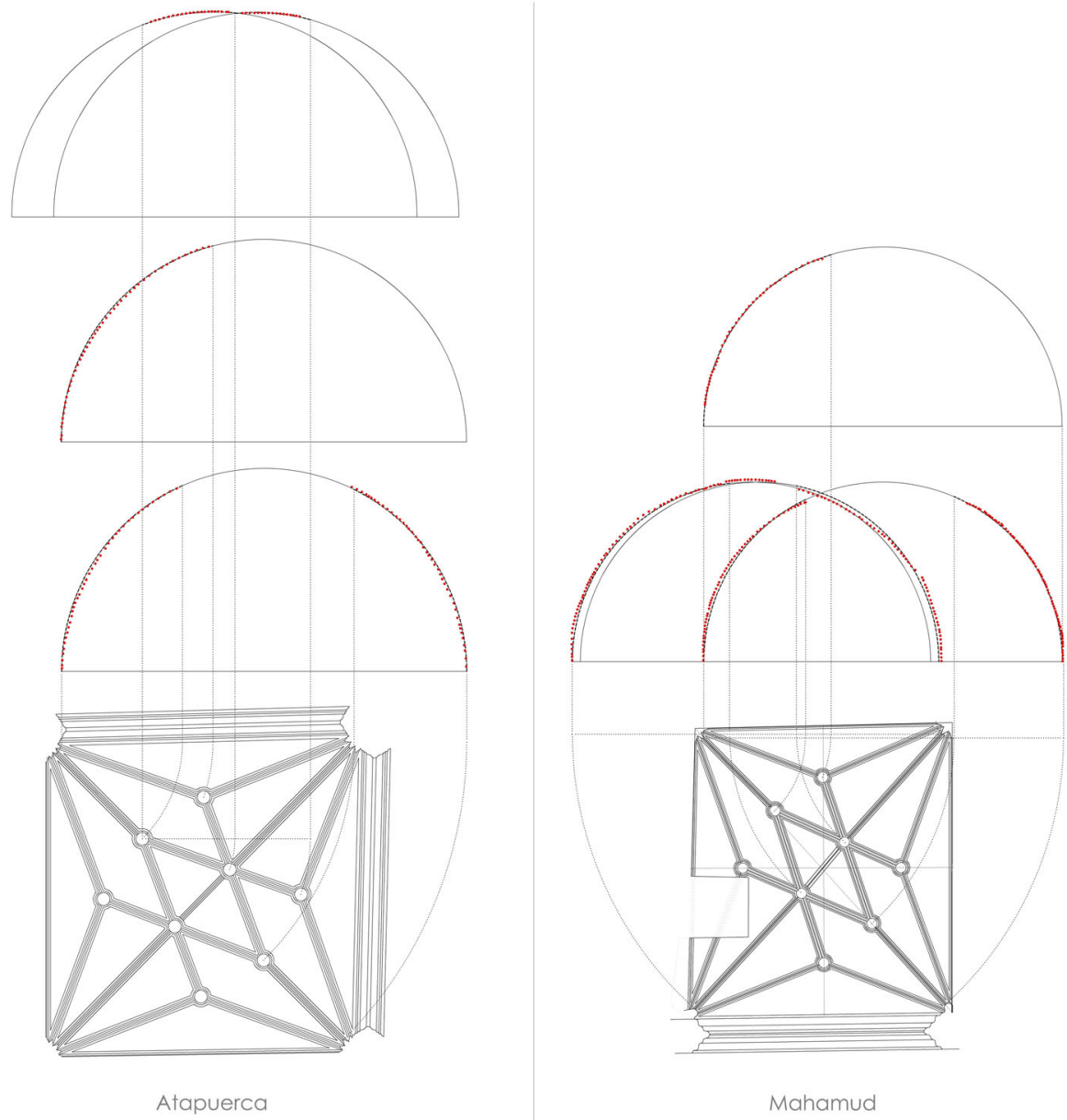

Fig. 13 Three-dimensional layout of the vaults at Atapuerca and Mahamud. Images: authors

Laying out the plan of a vault of this type may begin by determining the tiercerons. The repertoire of solutions which may be found in actual vaults is much richer than that present in original written sources. Spanish and French texts from the fifteenth and sixteenth centuries show square plan layouts with two different options: tiercerons aligned with the midpoint of the corresponding side (which gives as a result a location of the tierceron's keystone in one of the divisions of the axes into four equal parts) or tiercerons aligned with the intersection of the axes and the circumscribed circumference (each tierceron then follows the bisector of the wall arch and the diagonal rib). The methods of tracing the plan of the tiercerons that we have discerned in the analysed vaults seem not to be conditioned by a preconceived geometric concept. The process may be guided by the idea of placing a regular central figure (Zamora), keeping constant a distance to the perimeter arches (Mahamud) or locating the tierceron keystones in a point resulting from the division 

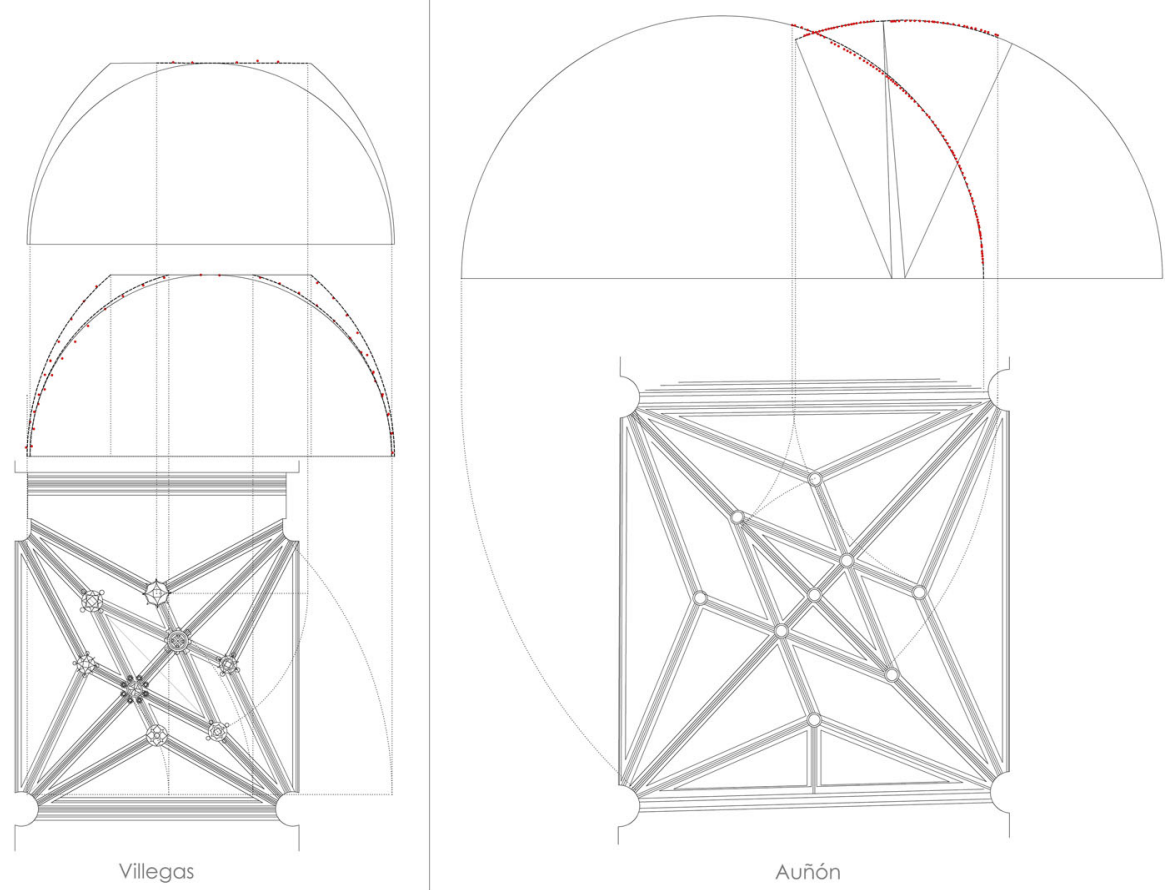

Fig. 14 Three-dimensional layout of the vaults at Villegas and Auñón. Images: authors

of one of the axes or the diagonal into any number of equal parts (the four remaining cases). When the vault spans a rectangular plan, the layout becomes more complex (Senent 2016) and solutions merge two different methods for determining the tiercerons: this is the case of Zamora and the vault at the church crossing of Bebenhausen Abbey (López-Mozo et al. 2015a).

The four earliest Spanish cases (Zamora, Segovia, Atapuerca and, partially, Mahamud, which were built between 1466 and 1511) may have used a main arch to guide the construction of the vault. They may have been designed using a single curvature to trace all the ribs. Similar procedures have also been found by the authors in a vault of this type built at Bebenhausen Abbey (López-Mozo et al. 2015a). In addition, the ribs of three of them (Zamora, Atapuerca and Mahamud) feature the same cross section, so all the voussoirs are identical and the construction process is simplified.

The vault built by Juan Guas in the cloister of Segovia Cathedral may have been designed following the guide of a main arch established by the unfolding of a way determined in the ground plan, giving as a result a radius smaller than half the 
diagonal. The use of this method may be related to the Breton origin of Guas's family. A significant number of layouts following this type of procedure are depicted in the Codex Miniatus 3 (ca. 1560-70) and in the treatise by Jakobus Facht von Andernach (1593). This method requires the radius of the main arch to be at least equal to the longest way that may be traced in the plan to reach a particular keystone. Then, when the design is guided by the use of a smaller, previously designed arch, other options must be considered. If the diameter of the main arch matches the diagonal of the plan, it may follow the method used by Ranisch, who places all keystones in the same sphere and connects them with portions of the main arch (see note 5). Alternately, the method used may be the one that can be recognized in actual vaults that manage to use the same curvature in all the ribs and solve adjustments by small displacements or rotations. This last option may be found in the vaults of Zamora, Atapuerca and Mahamud, as well as Bebenhausen Abbey.

The vault at Villegas seems to aim at laying out a horizontal central area; the vault at Auñón tries to solve the irregularities existing in the ground plan and in the heights of the transverse arches. Neither of these two vaults feature a single rib curvature, and neither show a layout of the ribs as sections of a sphere.

Spanish late Gothic builders usually avoided partially or completely removing the basic elements of a tierceron vault, especially the diagonal ribs and wall arches, as Central European masters did (López-Mozo et al. 2015b). This preference is evident in the way that the type of vault studied in this paper evolved in Spain, which gradually completed the diagonal ribs. Only four cases of our European collection of asymmetrical diamond design vaults feature one entire diagonal rib; three of them are in Spain in Atapuerca, Mahamud and Villegas, and the fourth is in Autun, in France. The vaults at Atapuerca and Mahamud feature this rib with a smaller cross section. In addition, this rib forms the smallest diagonal of the central rhombus, which in a rectangular plan results in non-alignment with the ground plan corners. The only case of our European collection that presents two entire diagonal ribs is the latest Spanish example, the vault at Auñón.

Our focus is the analysis of the geometrical construction of six Spanish examples to connect their three-dimensional design system with the methods used in Spain and Central Europe. We encounter six similar plan layouts but only three similar three-dimensional design methods, which can be found at Zamora (1466), Atapuerca (ca. 1500) and Mahamud (1511). Thus, similarities in appearance do not always support deeper connections. This paper is part of a larger work-inprogress on technical knowledge transfer. An overall analysis that compares the three-dimensional design of Spanish vaults with the designs of Central European vaults will be addressed elsewhere.

Acknowledgements This paper is part of the research project "Spanish late Gothic vaults construction in the European context. Innovation and knowledge transfer", which is funded by the Spanish Government (BIA2013-46896-P). We wish to thank Miguel Sobrino, Carmen Pérez de los Ríos and Arturo Zaragozá for providing data on the vaults in Zamora, Villegas and the sketches of the tracing house of Benissanó. We also want to express our gratitude to the priests of all the Parish churches and to the major of Mahamud, who so kindly gave us permission to collect data of the buildings. 


\section{References}

Adamski, Jakub. 2013. Remote artistic connections of the Late Gothic Church architecture in Lesser Poland: figured vaults in the Fifteenth century. In Artistic Translations between fourteenth and sixteenth centuries. Proceedings of the international seminar for young researchers. Warsaw: Institute of Art History, University of Warsaw.

Andernach, Jakobus Facht von. 1593. Architektur-Musterbuch des Jakobus Facht von Andernach. Historische Archiv Köln, Best. 7020 (W*) 276. Digital reproduction available at: http://historischesarchivkoeln.de/de/ lesesaal/verzeichnungseinheit/173118/Best.+7020+276+I.+Architektur-Musterbuch+des+Jakobus+ Facht+von+An.

Böker, Johann Josef. 2005. Architektur der Gothic_Gothic Architecture. Salzburg: Verlag Anton Pustet. Bucher, François. 1979. Architector: The Lodge Books and Sketchbooks of Medieval Architects. New York: Abaris Books Inc.

Bürger, Stefan. 2007. Figurierte Gewölbe Zwischen Saale und Neisse. Spätgotische Wölbkunst von 1400 bis 1600. Weimer: Verlag und Datenbank für Geisteswissenschaften.

Calvo López, José. 2017 (forthcoming). The Geometry of the Rib Vault in Early Modern Iberian and French Literature. Tecniche construttive nel Mediterraneo. Dalla stereotomia ai criteri antisismici.

Codex Miniatus 3. ca. 1560-70 Ms. Österreichische Nationalbibliothek, Vienna, available at http://www. onb.ac.at.

Delorme, Philibert. 1567. Le premier tome de l'Architecture. Paris: chez Federic Morel. Universitätsbibliothek Berne, MUE Bong IV 783/Public Domain Mark. Digital reproduction available at http:// dx.doi.org/10.3931/e-rara-15161.

Frankl, Paul. 1945. The Secret of the Mediaeval Masons. The Art Bulletin, Vol. 27, No. 1, 46-60.

García, Simón. 1681. Compendio de Arquitectura y simetría de los templos. Madrid: Biblioteca Nacional de España, Mss 8884. Digital reproduction available at bdh-rd.bne.es.

Gil de Hontañón, Rodrigo. c. 1560. Manuscrito (Included in Simón García, Compendio de Arquitectura y simetría de los templos, 1681). Madrid: Biblioteca Nacional de España, Mss 8884. Digital reproduction available at http://bdh-rd.bne.es.

Gómez Martínez, Javier. 1998. El gótico español de la Edad Moderna. Bóvedas de Crucería, Valladolid: Universidad de Valladolid.

Guardia, Alonso de. ca. 1600. Rasguños de arquitectura y cantería, BNE, ER/4196. Guardia's sketches and notes are drawn on copies of $\mathrm{B}$. Pittoni, Imprese di diversi principi, duchi, signori... Libro secondo, Venezia, 1566 and B. Pittoni, Imprese di diversi principi, duchi, signori... Venezia, 1568, placed under the same binding. Digital reproduction available at http://bdh-rd.bne.es. Search for «ER/4196».

Hammer, Hans. ca. 1500. Musterbuch. 15th-16th century. Ms. Cod. Guelf. 114.1 Extrav. at the Herzog August Bibliothek Wolfenbüttel. Digital reproduction available at http://diglib.hab.de/?db= mss\&list=ms\&id=114-1-extrav\&lang=en.

Huerta Fernández, Santiago. 2005. Informe sobre la estabilidad del cimborrio de la iglesia de San Juan de los Reyes, Toledo. Madrid: Instituto de Patrimonio Histórico Español. Digital reproduction. available at: http://oa.upm.es/698/1/Huerta_Inf_017.pdf.

Huerta Fernández, Santiago. 2016. Willis's sources on gothic vault construction. Robert Willis. Science, Technology and Architecture in the Nineteenth century. Madrid: Instituto Juan de Herrera, 297-320.

Ibáñez Pérez, Alberto Cayetano. 1991. Algunas obras burgalesas del escultor Juan de Esparza. Boletín del Seminario de Estudios de Arte y Arqueología. Vol. 57: 341-352.

Iborra Bernad, Federico. 2014. Algunas bóvedas olvidadas del siglo XVI. Bóvedas valencianas arquitecturas ideales, reales y virtuales en época medieval y moderna. Juan Carlos Navarro Fajardo (coord.). Valencia: Universidad Politécnica de Valencia, 5-31.

López-Mozo, Ana, Rosa Senent-Domínguez, Miguel Ángel Alonso-Rodríguez, José Calvo-López and Pau Natividad-Vivó. 2015a. Asymmetrical vaults in Late European Gothic: Basel and Bebenhausen as case studies. 5ICCH. Proceedings. 5th International Congress on Construction History. Construction History Society of America. Vol. 2: 497-504.

López-Mozo, Ana, Rafael Martín-Talaverano and Alberto Sanjurjo Álvarez. 2015b. Rasgos europeos en las bóvedas tardogóticas españolas. Casos relevantes. Actas del IX Congreso Nacional y I Congreso Internacional Hispanoamericano de Historia de la Construcción. Madrid: Instituto Juan de Herrera. Vol. II: 937-947. 
Martín Martínez de Simón, Elena. 2013. Arquitectura religiosa tardogótica en la provincia de Burgos (1440-1511). PhD Dissertation. University of Burgos.

Martín Talaverano, Rafael, Carmen Pérez de los Ríos and Rosa Senent Domínguez. 2012. Late German Gothic Methods of Vault Design and Their Relationships with Spanish Ribbed Vaults. Nuts and Bolts of Construction History, Culture, Technology and Society. París: Picard, III 83-90.

Merino de Cáceres, José Miguel. 1996. El claustro de la catedral de Segovia. Estudios segovianos 94: 477-507.

Muñoz Jiménez, José Miguel. 1987. La Arquitectura del Manierismo en Guadalajara. Guadalajara: Institución Provincial de Cultura "Marqués de Santillana".

Müller, Werner and Norbert Quien. 2005. Virtuelle Steinmetzkunst der österreichen und böhmishsächsischen Spätgotik. Petersberg: Michael Imhof.

Nussbaum, Norbert; Lepsky, Sabine. 1999. Das gotische Gewölbe. Eine Geschichte seiner Form und Konstruktion. Darmstadt: Wissenschaftliche Buchgesellschaft.

Palacios Gonzalo, José Carlos. 2006. The Gothic Ribbed Vault in Rodrigo Gil de Hontañón. Proceedings of the Second International Congress on Construction History. Cambridge: Construction History Society. 3 vols.: 2415-2431.

Palacios Gonzalo, José Carlos. 2009. La cantería medieval. La construcción de la bóveda gótica española. Madrid: Munilla-Lería.

Pliego de Andrés, Elena. 2011. La geometría de las bóvedas estrelladas en el gótico tardío alemán. Actas del Séptimo congreso Nacional de Historia de la Construcción. Madrid: Instituto Juan de Herrera, 1147-1156.

Rabasa Díaz, Enrique. 1996. Técnicas góticas y renacentistas en el trazado y la talla de las bóvedas de crucería españolas del siglo XVI. Actas del Primer Congreso Nacional de Historia de la Construcción. Madrid: Instituto Juan de Herrera, 423-433.

Rabasa-Díaz, Enrique, Miguel Ángel Alonso Rodríguez and Elena Pliego de Andrés. 2015. Trazado de bóvedas en las fuentes primarias del tardogótico: configuración tridimensional. Actas del Noveno congreso Nacional y Primer Congreso Internacional Hispanoamericano de Historia de la Construcción. Madrid: Instituto Juan de Herrera, 1399-1408.

Ramos de Castro, Guadalupe. 1982. La catedral de Zamora. Zamora: Fundación Ramos de Castro para el Estudio y Promoción del Hombre.

Ranisch, Bartel. 1695. Beschreibung aller Kirchengebaüde der Stadt Danzig. Danzig.

Reidinger, Erwin, Peter Csendes and Helmut Flachenecker. 2007. Die Schottenkirche in Wien: LageOrientierung-Achsknick-Gründungsdatum. In Österreichische Zeitschrift für Kunst und Denkmalpflege 2/3: 181-213.

Rixner, Wolfgang and Jerg Reiter. 1445-1599 (Rixner 1445-1515, and Reiter 1540-1599). Bauhüttenbuch des Wolfgang Rixner, Vienna, Albertina, Cim. VI, Nr. 5. Electronic facsimile submitted by the Museum.

Ruiz, Hernán. 1558-60. Arquitectura. Ms. Biblioteca de la Escuela de Arquitectura, Universidad Politécnica de Madrid. Digital reproduction available at: http://cdp.upm.es/R/NUNDQ2I63KPTJ58 JM1D3LPJL9S5IMKAIIIURQSQHDFJEXJ22Q9-04748?func=results-jump-full\&set_entry=00000 5\&set_number $=000270 \&$ base $=$ GEN01.

Senent-Domínguez, Rosa. 2016. La deformación del tipo. Construcción de bóvedas no-canónicas en España (siglos XVI-XVIII). PhD Dissertation, Escuela Técnica Superior de Arquitectura, Universidad Politécnica de Madrid.

Vandelvira, Alonso de. ca. 1575. Libro de trazas de cortes de piedras. Two copies are preserved: Alonso de Vandelvira, Exposición y declaración sobre el tratado de cortes de fábricas que escribió Alonso de Vandelvira, (manuscript), Library of the School of Architecture, Techical University of Madrid. Digital reproduction available at: http://cdp.upm.es/R/DN28DFTPAB2N7PG8VSJ3VAE6LEYU5X 8XU576DXUIYE3S3JPCSN-05444?func=results-jump-full\&set_entry=000005\&set_number=0002 $72 \&$ base $=$ GEN01.

Vicente Pradas, José María. 2016. Arquitectura gótica en Zamora y su provincia. PhD Dissertation, Universidad de Valladolid. Facultad de Filosofía y Letras. Digital reproduction available at http:// uvadoc.uva.es/handle/10324/16846.

Villaamil y Castro, José. 1903. Reseña histórica de la erección del Gran Hospital Real de Santiago, fundado por los Reyes Católicos. Galicia Histórica, ano II, n ${ }^{\circ}$ 8. Madrid. Digital reproduction available at http://www.galiciana.bibliotecadegalicia.xunta.es/gl/publicaciones/listar_numeros. cmd?submit=Buscar\&descendente=false\&busq_idPublicacion=642\&busq_anyo=1903\&campoOrden $=$ nombreordenar. 
Zaragozá Catalán, Arturo. 2008. El arte de corte de piedras en la arquitectura valenciana del cuatrocientos: un estado de la cuestión. Discurso de ingreso del académico electo Ilmo. Sr. D. Arturo Zaragozá Catalán, leído en el salón de Actos de la Academia el día 29 de enero de 2008. Valencia: Real academia de Bellas Artes de San Carlos de Valencia.

\begin{abstract}
Ana López-Mozo is an architect. Her Ph.D. dissertation was awarded the Extraordinary Doctoral Prize of the Polytechnic University of Madrid in 2009. She teaches Geometry, Architectural Drawing and Stonecutting at the School of Architecture of the Polytechnic University of Madrid. She also lectures in graduate courses on Construction History. Her research focuses on stereotomy, arches, vaults and domes and has appeared in international conference proceedings, peer-reviewed journals and books. She is now co-leading a research project on knowledge transfer in European late Gothic architecture, funded by the Spanish Ministry of Economy and Competitiveness.
\end{abstract}

Rosa Senent-Domínguez holds a Ph.D. in architecture. She worked as a specialized architect in the Eduardo Torroja Institute for Construction Science (IETcc) of the Spanish National Research Council (CSIC) (2005-2010). She has carried out collaborative teaching tasks at the School of Architecture of the Polytechnic University of Madrid in courses on Descriptive Geometry and Construction History. She is reviewer of the Journal Informes de la Construcción of the Spanish National Research Council (CSIC) and guest editor of the Journal "Construcción Histórica en Piedra - Historic Stone Construction". Informes de la Construcción, Vol. 65. N $^{\circ}$ EXTRA-2, Octubre 2013. ISSN: 0020-0883. 